\title{
Az iskola-egészségügy és a tanulási környezet korszerúsödése Magyarországon - a századforduló körüli évtizedekben
}

\author{
SANDA ISTVÁN DÁNIEL \\ Óbudai Egyetem TMPK \\ „Az épület czélszerü elrendezése, magassága, száraz volta, \\ szellőztetése, a benne feltalálható kényelem, \\ tisztaság, külső környékének csinossága, \\ a gyermekeknek nemcsak egészségök épségben való \\ fenntartására szolgál, hanem reájuk \\ nevelöleg is nagy befolyást gyakorol."1
}

Gönczy Pál

\begin{abstract}
A XIX. század végi Magyarország sajátos társadalmi, politikai és gazdasági viszonyait - az európai tendenciákkal párhuzamosan vizsgálva - jelentős változásokat tapasztalunk az iskolai terek minőségében. A higiéniai diskurzus kibontakozása; a kiegyezést követő gazdasági fellendülés, az építész-tervezők rendelkezésére álló új, egészségesebb építóanyagok, az iskolaorvosok követelései és a neveléstudomány szakembereinek pedagógiai érvei együtt eredményezték a szervezett nevelés-oktatás körülményeinek hazánkban soha eddig nem tapasztalt javulást. Kutatásomban ezt a folyamatot követem nyomon, és az elsődleges források elemzésével mutatom be a századfordulót megelőző és az azt követő évtizedben Budapesten kibontakozó interdiszciplináris diskurzust, amelynek eredményeként megszülettek az első javaslatok és állásfoglalások, majd törvényi előírások. Dolgozatomat kétirányú kitekintéssel zárom, mely szerint a fentiek egyenes vonalú következménye egyrészt a századelő falusi iskoláiban, másrészt a Bárczy-féle iskolaépítési akció során 36 fővárosi iskolapalotában megvalósult higiéniai és pedagógiai szempontokból egyaránt példaértékú tanulási környezet.
\end{abstract}

Kulcsszavak: iskolaépítészet, iskola-egészségügy, higiéniai diskurzus, dualizmus

\footnotetext{
${ }^{1}$ Gönczy Pál (1888): A népoktatás Magyarországon. In: Gönczy Pál (1888): Tanulmányok. Budapest. 344-345.
} 


\section{Bevezetés. Az ISKOlA MINT A GYERMEK TESTI-LELKI EGÉSZSÉGÉNEK LETÉTEMÉNYESE}

"A XIX. században kiteljesedo modernizáció nyomán az európai iskolaügy fejlodésének is új szakasza kezdődött. A század végére - a modern nemzetállamok nagy ellátórendszereinek részeként - létrejöttek a nyilvános, kötelezö, új szakmai szinvonalon kialakitott, és általános szinten megfogalmazott feladatokat ellátó állami jóváhagyások és elvárások szerint müködő nemzeti közoktatási rendszerek." (Németh, 2012. 40.).

A XIX. század végi Magyarország sajátos társadalmi, politikai és gazdasági viszonyait - az európai tendenciákkal párhuzamosan vizsgálva - jelentős változásokat tapasztalunk az iskolai terek minőségében. A higiéniai diskurzus kibontakozása; a kiegyezést követő gazdasági fellendülés, az építész-tervezők rendelkezésére álló új, egészségesebb építőanyagok, az iskolaorvosok követelései és a neveléstudomány szakembereinek pedagógiai érvei együtt eredményezték a szervezett nevelés-oktatás körülményeinek hazánkban soha eddig nem tapasztalt javulást. Kutatásomban ezt a folyamatot követem nyomon, és az elsődleges források elemzésével mutatom be a századfordulót megelőző és az azt követő évtizedben Budapesten kibontakozó interdiszciplináris diskurzust, amelynek eredményeként megszülettek az első javaslatok és állásfoglalások, majd törvényi előírások. Az oktatáspolitika az iskola-egészségügyi követelmények szigorítását, illetve betartatását a Vallás- és Közoktatási Minisztérium (VKM) rendelettel írta elő. 1905-ben orvosok és egészségtanárok javaslata jelent meg egy „mintaiskola" építésére, melynek tervezetét - levéltári kutatásaim alapján - részletesen ismertetem.

A pedagógiai terek korszerúsödése, differenciálódása és funkcióváltozásai a pedagógiai-pszichológiai elvek és nézőpontok, vagyis a pedagógia szakszerûsödésének következménye. A szakszerúség fokozódása és a pedagógiai munka hatékonysága szimbiózisban segítik egymást, és formálják a pedagógiai teret, tehát egy-egy új térszerkezet megvalósulását mindig megelőzik az új felismerések alapján megfogalmazott elvárások.

Nóbik Attilával egyetértve a fogalmak hierarchiájában ,[...] érdemes megküilönböztetni az iskolai tér, a pedagógiai tér és a szakmai tér fogalmát." A pedagógiai tér ebben a tanulmányban a konkrét épített/mesterséges környezetet jelenti, vagyis az iskolaépületet, annak környezetét és berendezését (v.ö. Nóbik, 2015. 94. o.).

Dolgozatomat kétirányú kitekintéssel zárom, mely szerint a fentiek egyenes vonalú következménye egyrészt a századelő falusi iskoláiban, másrészt a Bárczyféle iskolaépítési akció során 36 fővárosi iskolapalotában megvalósult higiéniai és pedagógiai szempontokból egyaránt példaértékú tanulási környezet.

\section{Az ELSŐ NAGY ISKOLAÉPÍTÉSI HULLÁM A FŐVÁROSBAN}

\section{II.1. Társadalomtörténeti előzmények}

A modern, illetve funkcionális iskolai terek XIX. századi európai szakszerúsödési folyamatainak, illetve a XIX. századi hazai iskolaépítészetben is megjelenő 
változásainak hátterében a modern kapitalizmus különböző makroszintú folyamatai állnak. Ezek egyik alapvető eleme a modern ipari tömegtermelés, az ennek velejárójaként kialakuló egzakt időütemezés (az óra uralma, a modern teljesítménykényszer) fegyelmező ereje, a nagyarányú urbanizációs folyamatok kiteljesedése. Miként Foucault és Elias elemzései azt bemutatják, az önkontroll és a fegyelem a civilizációs folyamatok természetes velejárója (Elias, 1986, Foucault, 1990). A szégyenérzet és a kimért pontosság megjelenése, a testi megnyilvánulások, a külső és önkontroll megerősödése, az emberi habitusnak a munka során, illetve hatására kialakuló jellegzetes új vonásai. Ebben az időszakban minden területen megerősödik az egyén feletti állami társadalmi kontroll is, kialakul annak sajátos differenciált intézményrendszere (kaszárnyák, börtönök, kórházak, szegényházak, elmegyógyintézetek), mely változások az iskolai ellenőrzés és fegyelmezés terén is erőteljesen érvényesültek (V.ö. Foucault, 1990. 243-251. o.).

A korszak sajátos paradoxona, hogy az egyén társadalmi mozgásterének látszólag jelentős mértékú növekedése mellett egyre erőteljesebbé vált a nevelés által kialakított belső kontroll, az egyén megnövekedett mozgásterének ellensúlyozására a társadalmi ellenőrzésnek jól szervezett, differenciált állami intézményei jönnek létre. Ezek sorában főszereplőként az ekkor már mindenki számára kötelező iskola kapott központi szerepet a normálisnak elfogadott egyéni viselkedés kialakításának, jól szervezett állami ellenőrzésének folyamatában. Ez az igény jelentős mértékben hozzájárul a modern tömegoktatás, majd a XX. században a felnőttoktatás intézményhálózatának kialakulásához, valamint ezzel kölcsönhatásban a képzésben résztvevők hatékony munkaerővé válását elősegítő jól szervezett intézményi szocializációs folyamatok kialakulásához (Németh, 2012. 49. o.).

Miként Georges Canguilhem (2004) munkájának elemzése alapján megállapítható, a norma és a normális fogalmak a XIX. századi gondolkodás sajátos produktumai. Leginkább a korszak európai kórház- és iskolareformjaiban megjelenő modern racionalizációs folyamatokhoz, illetve az azokkal összefüggő, az építkezés terén is megfigyelhető szabványosítási-szakszerúsödési folyamatokhoz köthetők. A racionalizálási folyamatok részeként megjelenő normalizálás olyan kollektív igények kifejeződése, melyek összessége, még ha az az egyes egyénekben nem is tudatosul, megmutatja, hogy egy adott társadalom egy adott korban hogyan értékeli saját szerkezetét, ahhoz viszonyítva, amit a legfőbb jónak tart. A külső vagy belső norma alapján normálisnak minősített tárgy vagy tény azután minden esetben vonatkozási pontként szolgálhat más tárgyak és tények számára, melyek még várnak arra, hogy normálissá nyilvánítsák (Németh, 2008. 94. o.).

Ennek pedagógiai vetületeként jelenik meg már a felvilágosult abszolutizmus hatására a norma-, illetve normáliskola fogalma, vagyis az az iskola, ahol tanítani tanítanak, ahol a „normális” pedagógiai ismereteket kikísérletezik, illetve ennek nyomán a XIX. századtól kezdődően egyre szigorúbb szabványok szerint kialakított iskolaépület. A normaiskola az a hely is, ahol a leendő pedagógusok a megfelelő munkához szükséges szakismereteket, mint a munkájukat irányító normák rendszerét elsajátítják. Részben Canguilhem nyomán állapítja meg Michel Foucault a Felügyelet és büntetés címú munkájában, hogy a XIX. században 
kibontakozó totális fegyelmezőrendszerek mögött a modern társadalom mintegy alapvető törvényeként mindig ott áll a norma hatalma, amely a felügyelet mellett a hatalom alapvető eszköze. A norma lesz a kényszerítő hatalom legfőbb legitimációs eszköze az oktatásban is, annak sztenderdizálódása során, amikor megjelennek a „normál” főiskolák. Ez jelenik meg a XIX. századi orvosképzés és kórházrendszer kialakítása során, amelyek az egészség általános normáit hivatottak érvényesíteni, de ott van az ipari termelés eljárásainak és termékeinek korabeli szabványosításában is. A normalizáló hatalom bizonyos értelemben egynemúségre kényszerít, de egyben individualizál is azáltal, hogy lehetővé teszi az eltérések mérését, a színvonal meghatározását, a specialitások megállapítását, és az egymáshoz illesztett különbségek hasznosítását (Vö. Foucault, 1990. 251. o.).

A felvilágosodástól kezdődően kibontakozó modern higiénia mindazoknak a tudástartalmaknak a foglalata volt, amelyek egyrészt arra irányultak, hogy leírják az ember viszonyulását azokhoz a materiális feltételekhez, amelyek meghatározzák fizikai-testi megnyilvánulásait. Másrészt az individuumokat és a társadalmi tér egyéb szereplőit eligazítsa abban, hogy miként tudja ezeket szabályozni. Ez a hatalmas terület magába foglalta az ezzel kapcsolatos tudás, gyakorlati cselekvés és különböző technológiák rendszerét. Amennyiben ennek pedagógiai oldalát, leginkább az iskolai higiénia, illetve iskolai egészségtan keretében megjelenő elemeit vizsgáljuk, megállapíthatjuk, hogy a normális itt is központi kategória (normális testtartás, írás, ruházat, az iskolaépület normái, annak norma szerinti bútorai). Az így megkonstruálódó normális, illetve a normalitás egyre inkább egy experimentális módszerekkel vizsgálható előírt normát, mérhető átlagot jelentett (Németh, 2008. 94.; Németh, 2012. 76. o.).

E folyamatok sajátos manifesztációját követhetjük nyomon a századfordulót megelőző és az azt követő évtizedek Magyarországának, és benne mindenekelőtt a fővárosnak, Budapestnek a fejlődésében.

\section{II.2. Az iskola egészségügy helyzete a XIX. század végén}

Az abszolutizmus korát követően az 1867-es kiegyezés (az 1867. évi XII. törvény) új alapokat teremtett a Lajtán inneni és a Lajtán túli birodalomrészek viszonyában. A részleges önállóság - külön parlament és kormány - az oktatásügyben is a gyors változások kezdetét jelentette. Az Andrássy-kormány vallásés közoktatásügyi minisztere ismét báró Eötvös József lett, mint 1848-ban. Az új politikai helyzet reformelképzeléseinek tág teret nyitott. Megtervezte a teljes magyar oktatásügy átszervezését, de legfontosabb feladatának a népoktatás ügyét tekintette. Eötvös legfőbb és legsokoldalúbb segítője Gönczy Pál a kiváló pedagógus, pedagógiai író és miniszteri tanácsos. Az ő jelentéseiből tudható, hogy a korabeli iskolaépületek nagy része alkalmatlan volt a tanításra és messze nem felelt meg a jogszabályi előírásoknak (Mikonya, 2015. 146. o.).

A parlament 1868 őszén fogadta el a XXXVIII. törvénycikket „A népiskolai közoktatás tárgyában” címmel. Ennek értelmében minden gyermek hatodik életévétől 12 éves korig köteles nyilvános iskolába járni. Akik nem tanultak 
tovább valamilyen középiskolában, 15 éves korukig ismétlő iskolai tanításon voltak kötelesek részt venni. A törvény értelmében az elemi iskolának tehát két tagozata volt: a hat tanévig tartó mindennapi elemi iskola és a három éves ismétlő iskola, ami a téli időszakban hetenként egy vagy két félnapig tartott.

A törvény a községeket kötelezte az elemi iskolák létesítésére és fenntartására, hasonlóan, mint az 1848-as tervezet. Az állam elismerte a meglévő felekezeti elemi iskolákat, s a törvényben előírt feltételek mellett lehetővé tette újak nyitását is. Társulatok, magánszemélyek is múködtethettek elemi iskolákat, de valamennyi felett az államnak felügyeleti és ellenőrzési joga volt.

Az oktatás az elemi iskolákban anyanyelven folyt. A megnövekedett számú népiskolákat tanítókkal kellett ellátni, ezért a kultuszminiszter Eötvös 20 tanítóképző építéséről döntött. A törvény megjelenésekor a tankötelesek 48 \%-a járt iskolába, 1872-ben pedig már az 55 \%-a, viszont a besorozott katonák 22 \%-a analfabéta volt (Gönczy, 1888).

Pest, Buda és Óbuda 1873-ban történt egyesítése után felgyorsult a főváros világvárossá fejlődése. Hatalmas építkezések kezdődtek: tömeges bérlakásépítés, középületek, pályaudvarok építése vette kezdetét, de az épületállomány gyarapodása nem tudott lépést tartani a lakosság számának rohamos növekedésével.

Jóllehet az 1880-as évtized nem jelentett korszakváltást az iskolaépítés terén, de a korszerú iskolák építésével kapcsolatos követelmények ekkor fogalmazódtak meg. A fejlesztési elvek kidolgozásához a hazai szakemberek elsősorban a nálunk gazdagabb és fejlettebb közoktatással rendelkező országokból szereztek információkat.

A Herbart-tanítvány Karl Volkmar Stoy (1815-1885) 1844-ben Jénában igen korszerú iskolát létesített. A jól tájolt épület védett az utca zajától. A kertben sportpálya és fákkal körülvett játszótér található. Az iskolához gazdálkodásra alkalmas kert, díszkert, faiskola, növényházak, botanikus kert és gyümölcsös valamint szabadtéri órák tartására alkalmas kerti lugas is tartozott. A külsőre is impozáns, középen karcsú toronnyal ellátott kétemeletes épület földszintjére nagy tornatermet terveztek, ami akkoriban még ritka volt. Mellette osztálytermek és tanári lakások helyezkedtek el. Az emeleti díszteremhez tágas lépcsősor vezetett, ahol az iskola minden tanulója számára elegendő ülőhelyet biztosítottak (Mikonya, 2002. 31. o.).

A Néptanítók Lapjában 1881-től találunk írásokat nyugat-európai, elsősorban francia és észak-amerikai iskolaépületekről. A tanulmány külön kiemeli az épület belső kialakítását és berendezési tárgyait: „,...] a folyosók szélesek, a tantermek tágasak, az iskolák szerves részei a mosdók, a könyvtárak. A tantermekben ivóvíz van, a folyosókon cipő- és ruhakefék." (Néptanítók Lapja. 1882. 70. o.).

Eötvös minisztersége után, Pauler rövid lélegzetú miniszteri múködését követően kezdődött Trefort Ágoston 16 éves közoktatási minisztersége (1872-1888). Trefortot idézve „... a közoktatás és a közegészségügy egyszersmind gazdasági kérdés is, amely meghatározza a termelés egyik legfontosabb tényezőjének, az embernek testi és szellemi állapotát." (Trefort, 1885. 3. o.). Kiemelkedő közoktatásügyi és közegészségügyi szervező munkájában segítségére volt terveinek részbeni megalkotója, részben kivitelezője - az egyetemi ügyek irányítója a 
minisztériumban - Markusovszky Lajos, akit még Eötvös vett maga mellé. Trefort minisztersége alatt fogadta el a parlament 1876-ban a közegészségügyi törvényt, amely állami feladattá emelte a közegészségügyet, szervezeti felépítésének létrehozását és ellenőrzését. A törvény „legnagyobb hiányossága” abban rejlett, hogy számos szempontból meghaladta az akkori lehetőségeket. Továbbá, a törvény nem intézkedett az iskolaegészségügyről és a higiénia oktatásáról sem.

\section{II.3. Fodor József, a higiénia és az iskolaorvoslás hazai meghono- sítója}

Fodor József (1843-1901) az iskolaegészségügy megalapítója. Nevéhez fűződik az iskolaorvosi-egészségtanári intézmény bevezetése. A közegészségügyi törvény kritikájában több szakember rámutatott, hogy a törvény nem intézkedett kellő mértékben az iskolaegészségügyről. E hiány pótlásában elévülhetetlen érdemei voltak Fodor Józsefnek, aki az iskolaegészségügyet a higiénia önálló, alkalmazott területének tekintette, amely az orvosi, a higiéniai és a pedagógiai elveket együtt alkalmazza az oktatás színterén. Ennek irányítója a szakszerúen kiképzett iskolaorvos, akinek feladatai nemcsak a közegészségügyi elvek és törvények közvetlen végrehajtása és ellenőrzése, hanem az egészségtan tanításán keresztül a jövő nemzedékében az egészséges életmódra való nevelés feltételeinek kialakítása is.

„...A hygienét általában és rendszeresen oktatni kell, mert a hygiene az egyén számára munkaképességet és a lakosság humánus érzékét kifejleszti" - írta 1887-ban (Fodor, 1887. 4. o.).

Már a közegészségügyi törvény előkészítésének szakaszában felhívta a figyelmet annak a szakmai szempontnak az érvényesítésére, hogy a felnövekvő nemzedék számára közegészségügyi hatóságok által engedélyezett iskolaépületeket emeljenek. Gondosan tanulmányozni kell az iskola környékét, talaját, magának az épületnek csatornázottnak, folyóvízzel ellátottnak kell lenni, a tantermek pedig világosak, jól szellőztethetőek kell, hogy legyenek. Ezeket olyan alapkövetelménynek tekintette, amelynek megléte nélkül nem szabad iskolaépületet használatba adni. Ugyancsak fontosnak tartotta, hogy a gyermekek életkori sajátosságainak és fejlettségüknek megfelelően kerüljenek iskolába, ahol a fokozatosság elvét követve szabad őket szellemileg terhelni. A folyamat legfőbb "ellenőre" a szakképzett iskolaorvos, aki nemcsak a gyermekek testi és szellemi fejlődését kíséri figyelemmel, hanem higiéniai ismeretek oktatásával is bekapcsolódik a tanításba. Az iskolaorvos tevékenységi területe nemcsak az iskola, hanem a gyermekek családi környezete is. Csak teljes információk birtokában lehet eredményes a munkája, tudja igazán eredményesen nyomon követni a gyermekek testi és szellemi fejlődését. Fodor József szorgalmazta a testnevelés bevezetését is, valamint olyan jogszabályok megalkotását, hogy az iskolaorvos a gyermekek védelmében felléphessen a szellemileg túlzottan igénybevevő tanárok ellen (Katona, 1963, 135-139. o.).

A közegészségtan professzoraként részt vett a Budapesti Királyi Orvosegyesületben tartott vitán, ahol észrevételezték a közegészségügyi törvény eredeti fogalmazványát. Fodortól származik a 27. § szövegmódosítása: „Az iskolák czélsze- 
rübb épitése a gyermekek testi kifejlődésére és egészségére nem egyszer felettébb károsan folyt be, minél fogva szükséges, hogy az iskolák épitése közegészségügyi szempontból a törvényhozás különösen fontos tárgyát képezze."2

Fodor közegészségügyi szemléletének másik - témánk szempontjából kiemelten fontos területe az egészségügyi felvilágosítás. Lényeges feladatnak tekintette a felvilágosítás megkezdését a legkisebb korban, hiszen az egészséges életmód kialakításának legfőbb feltétele az erre való rendszeres nevelés, a helyes ismeretek átadása és az annak megfelelő életmód kialakítása. E tevékenység lényeges fórumának az iskolát tekintette. Részletes javaslatot készített az iskolát látogató korosztály életkori sajátosságait, a testi nevelés, valamint a szellemi adottságok vizsgálatára, amelyeknek a felügyeletére az iskolaorvost rendelte ki, aki egyben az egészségtant is tanította.

Iskolaegészségügyi elképzelései a középiskolai iskolaorvosok és egészségtanárok képzéséről és alkalmazásáról szóló 48281/1885. sz. vallás és közoktatásügyi miniszteri rendeletben és annak 44250/1887. sz. végrehajtási utasításában valósultak meg. Már a törvény megjelenése előtt vita robban ki arról, hogy a népiskolákban is szükséges-e ennek tanítása, vagy csak a középiskolákban. Fodor arra a - későbbiekben helyesnek bizonyult - álláspontra helyezkedett, hogy mindkettőben szükséges. Ragaszkodott a középiskolai egészségtan oktatásához, a népiskolákban pedig elemi egészségvédelmi, higiéniai és életmentési ismeretek tanításához.

„Az elemi népiskola a köznépnek azt a millióit látja el egészségtani ismeretekkel, amely magasabb müveltséget nem szerez és magasabb iskolákba nem jut. Ezt a népet kell mindenekelőtt egészsége védelme tekintetében felvilágosítani: annál inkább, mert éppen a köznép szenved a legtöbbet munkájával, mostoha életviszonyaival, értelmetlenségénél fogva egészségében. Ellenben a népiskolában a hygiene humanisztikus feladatainak fejtegetése szükebb határok között mozoghat..." - olvashatjuk az Egészség címú folyóiratban 1887-ben megjelent „Iskolaorvosok és egészségtanárok a középiskolában" címú írásában. (Fodor, 1887. 11. o.).

A fentiekből jól látható, hogy egyrészt fontosnak tartotta az alacsonyabb iskolázottságú vidéki lakosság közegészségügyi felvilágosítását, másrészt a koncentrikus tananyagelrendezés elvét követve - a népiskolai egészségtan alapkérdéseit bővítette ki, emelte középiskolai színvonalra, miközben figyelembe vette a tanulók biológia, fizika és kémia tantárgyban megszerzett ismereteit. E gondolatkört az Orvosi Hetilapban 1885-ben „Középiskolai hygienetanárok és iskolaorvosok” címú írásában így indokolja: „... Az ember nem csupán szellemből áll, hanem testből is, amely testet az élet szükségletei ugyancsak megterhelnek. E testet az iskolai ártalmasságok ellen meg kell védelmezni, azt éppen ifjú korban, a középiskola éveiben, éppen úgy mint a szellemet, az életre előkészíteni." (Fodor, 1885. 11. o.).

Az iskolaorvosok összekötő szerepet töltöttek be az adott iskola és a közegészségügyi hatóságok között. Azonban az iskolaorvosi munka hatékonyságát korlátozta, hogy minden lényeges intézkedést az iskolaigazgató engedélyétől

\footnotetext{
${ }^{2}$ A Budapesti királyi Orvosegyesület iratai. 1876. évi bizottsági jegyzőkönyvek. (Idézi: Antall J. Kapronczay K. (1975).
} 
tettek függővé. Ugyanakkor elmondható, hogy a magyar iskolaegészségügyi törvény a maga korában az első ilyen jellegú európai törvény volt (Aujenszky, 1905, 29. о.).

\section{II.4. Fodor munkásságának hatása}

A következő években magyar iskolaorvosok és építészek Svájcban és Ausztriában tett tanulmányútjaikról készült jelentésekben számolnak be tapasztalataikról, melyek szerint a hazai iskolaépítés számára példaként szolgálhat, hogy az új osztrák iskolákban „a tantermek négy méter magasak, a ruhatár a folyosón van elhelyezve, hogy összefüggö ablaksorok vannak, és a fütés központi." (Dékány, 1903. 234-238. о.).

Az 1906. február 17-i hatállyal kelt 14532. sz. rendelet az iskolaorvosok ellenőrző jogát kiterjesztette a népiskolákra is, de következetes végrehajtása az anyagi erőforrások hiányában elmaradt, az orvosok tevékenysége csak a szúrővizsgálatokra korlátozódott (Tigyi, 2013. 2. 227. o.).

Néhány évvel később, 1909-ben a Magyar Népiskola címú folyóirat arról adott hírt, hogy Londonban az iskolák céljára rendelkezésre álló telkek szúkössége miatt "az iskolák tetején játszótereket alakítanak ki” (Magyar Népiskola. 1909. 7. o.). ${ }^{3}$

A korabeli magyar sajtóban e tárgykörben megjelenő írások tartalma és a témával foglalkozó tanulmányok számának gyors emelkedése meggyőzően bizonyítja az oktatáspolitika, iskolaorvosok és pedagógiai szakemberek fokozódó érdeklődését e kérdések iránt. Ezt igazolja a Néptanítók Lapjában folyamatosan megjelenő kifejezetten egészségügyi problémákat feldolgozó cikkek, tanulmányok sora, amelyeket a tanítók publikáltak.

\section{II.5. Az iskolaépületek állapota a dualizmus korai időszakában}

Objektív tényeket vizsgálva az iskolák zsúfoltságának legjobb mutatója az egy tanteremre jutó tanulók száma. Az iskoláztatás helyzetét a fóvárosban alapvetōen meghatározta az a körülmény, hogy az iskolák jelentős része eredetileg más célra épült épületben, zömmel bérházakban múködött. A helyzet lassú javulását mutatja, hogy míg 1869-ben a népiskolák 76 \%-nak, tehát a háromnegyedének volt saját épülete, ez a szám csak a millennium idején érte el a 90 \%-ot (Pogány, 1928. 148-181. o.).

Trefort Ágoston kultuszminiszter már 1873-ban több középiskola épületét alkalmatlannak tartotta, ezért ebben az évben rendeletet adott ki, melyben felhívta az intézmények vezetőinek figyelmét, hogy „,...ki-ki az iskolát ne csak jó karban tartsa, de a kello" szellöztetés, célszerü padrendezés és minden irányu tisztaság

\footnotetext{
${ }^{3}$ Ehhez bővebben lásd: School Architecture in England in the later 19th Century. In: Franz-Josef Jelich - Heidemarie Kemnitz (2003, szerk): Die pädagogische Gestaltung des Raums. Bad Heilbrunn Verlag Julius Klinkhart 221-229. Magyar nyelven: William Filmer-Sankey: Iskolaépítészet a 19. század végén Angliában. Neveléstörténet 2008. 3-4. sz. Ford. Sanda István Dániel) (Filmer-Sankey, 2008.)
} 
által az egészségügyet tehetsége szerint előmozdítsa."(Részlet a VKM 30479/1873. számú rendeletéből).

Vidéken pedig - ahol egyáltalán volt iskola - az egy tanteremre és tanítóra jutó tanulók száma átlagban 80-90 fő között mozgott, de nem volt ritka az sem, hogy egy tanteremben 120 gyermek volt bezsúfolva, a 6 üléses padban 13-15-en szorongtak.

Benisch Arthur így ír az 1869-1900 között épült nem állami iskolákról: „A tantermek nagyrészt silányak, alacsonyak, sötétek, nedvesek, mert egyszerü parasztlakásokat, istállókat, kocsmákat, elavult községházakat s egyéb, más célra nem használható épületeket alakítottak át iskolák céljaira." (Benisch, 1928. 97. o.).

Hasonlóan jellemezte a korabeli iskolákat Kunfi Zsigmond: "Belépve valahová egy odúba: tanteremnek nevezik fájdalmas nagyzási hóbortból. A padló nagy területen ki van rohadva. A falak nyirkosak. Egy nagy térkép, néhány növényt vagy hazafias jelenetet ábrázoló történelmi kép lerohadt a nedves falról és cafatokban csüng alá. [...] Rozoga, megrepedezett vaskályha telepipálja füstjével a termet." (Kunfi, 1913. 7-8. o.). E politikai brossura megállapításai meglehetősen tendenciózusak. Annál inkább elgondolkoztató, hogy az idézett szakaszban megfogalmazott vélemény mégis összecseng a konzervatív, kormánypárti Benisch Arthur fent megfogalmazott megállapításaival.

A hivatalos statisztikai adatok szerint a történelmi Magyarországon 1913-ban egy tanteremre 60 tanuló jutott (Illyefalvi, 1925).

A nemzetiségek által lakott vidékek iskolaépületeit tekintve - még a hivatalos források szerint is - a helyzet az országos átlagnál sokkal rosszabb volt. Az ellenzéki Nemzeti Iskola címú folyóiratban 1913-ban a falusi iskolákról azt olvashatjuk, hogy azok "szánalmas zúgok, amelyek nemcsak hogy a kívánt és eloírt célnak nem felelnek meg, de határozottan kárára vannak az oktatásügynek." (Nemzeti Iskola. 1913. 2. o.).

\section{II.6. Budapesti iskolaépületek}

Amint a fentiekből jól látható, a fóvárosi iskolák helyzete kedvezőbb volt a vidékieknél. A gyorsan fejlődő világvárosban azonban egyre nagyobb gondot és speciális problémát jelentett az iskolák elhelyezése, az optimális méretú udvar biztosítása. 1899-ben egy vizsgálat során 20 iskola fekvését vették szemügyre.

Például a József utcai polgáriban $0,40 \mathrm{~m}^{2}$; a Rottenbiller utcai elemiben pedig $0,29 \mathrm{~m}^{2}$ volt az egy tanulóra jutó alapterület.

A század eleji fővárosi iskolák tényleges helyzetének megítéléséhez különösen értékes az a dokumentum, amelyet Szabó Sándor és Magyarevits Mladen 1906-ban állított össze az iskolaépületek egészségügyéről.

A terjedelmes anyagból kiemelve egy jellemzó értékelést, a tipikusnak nevezhető problémákat olvashatjuk. Például az I. kerületi Attila utcai főgimnáziumban: „Kevés a köpőcsésze. A vizelők száma elégtelen, azok büdösek, a folyosók nincsenek fútve, az udvar kicsi, nincs megfelelő játszótér. Az 1/B. osztály zsúfolt, $1 \mathrm{~m}^{2}$ terület jut egy tanulóra." A részletes helyzetkép alapján a jelentés készítői az alábbiakat tartották a legfontosabbaknak: az árnyékszékek 
rendben tartását; a megfelelő fútést és világítást; a zsúfoltság megszüntetését; a tornatermekben linóleumpadló alkalmazását.

Jóllehet a hazai iskolaépületekről általánosságban elmondható, hogy elmaradottak és szinte kivétel nélkül egészségtelenek voltak, ennek ellenére nem szabad lebecsülnünk azokat a központi törekvéseket és iskolaorvosi előírásokat, amelyek - ha nem is hoztak azonnal eredményt - előfeltételét jelentették a fokozatos javulásnak, változásnak.

\section{II.7. A VKM intézkedései, az iskolaorvosok és a pedagógusok törekvései}

Az 1868. évi XXXVIII. törvény kimondta, hogy „Az újonnan épitendő iskolaépületek egészséges helyen épüljenek, száraz, s a gyermekek létszámához mérten - egy tanteremre 60 gyermeket és minden gyermekre legalábbis 8-12 lábnyi helyet számítva-elegendo" számú világos és könnyen szellőztethetö tantermekkel legyen ellátva." (Ehhez bővebben lásd: az 1868. évi XXXVIII. törvénycikk 27. §-át.)

Tehát, pedagógiai és egészségügyi szempontból megfelelő iskolák építésére korábban is voltak törekvések, de a törvény végrehajthatatlanságát a miniszter 1894-ben maga is elismerte, amikor megállapította, hogy az "1868. évi XXXVIII. törvénycikk az iskolaházakról és tantermekröl rendelkezett ugyan, de az általános feltételek mellett a felïgyelö hatóságoknak nem biztosították azt a jogot, hogy az építendő helyiségeket elözetesen elbírálja, azokat jóváhagyja, illetve az építési engedélyt megtagadja. Szabályrendeletileg sem volt az ügy rendezve."4

Az iskolaépületek törvényi előírásokhoz igazodó megvalósítása csak igen lassan vált gyakorlattá. A már idézett Gönczy Pál - nyilvánvalóan a realitások alapos ismeretében - 1879-ben 80 főre tervezett tanterem építésére tett javaslatot (Benisch, 1928. 97-125. o.). Ez nyilvánvaló visszalépés a törvényben elfogadott maximum 60 fős osztálylétszámmal szemben. Gönczy Pál tisztában volt az ország anyagi helyzetével, így azt szorgalmazta, hogy lépésről-lépésre felépíthető, bővíthető intézményeket tervezzenek. Különösen vonatkozott ez a nagyobb tanítóképzést szolgáló intézményekre, ebben az esetben a helyszín megváltoztatását tartotta fontosnak, amennyiben a tanítóképzők központi elhelyezést tartotta előnyösnek (Mikonya, 2015. 155. o.).

Kéri Katalin hasonló megállapítást tesz a századforduló körüli vidéki iskolák épületeinek bemutatásakor: „XX. század elején a gazdasági fejlődés ellenére - mintha megállt volna az idő az iskolaépitkezéseket illetően. A tanfelügyelői jelentések, az iskolaszéki kérelmek és az újságcikkek alig változtak tartalmukat tekintve a múlt század utolsó harmadában íródottakhoz képest." (Kéri, 1995. 197-221. o.).

Mindezekkel együtt a századfordulót megelőző évtizedekben a szemléleti változások is érzékelhetőek. Építészek, iskolaorvosok és pedagógusok egyaránt követelik az építkezéseknél a pedagógiai és egészségügyi követelmények egyre szigorúbb figyelembe-vételét. Ez a törekvés azért került az érdeklődés homlokterébe, mert egyrészt az egészségtelen helyiségekben nagy tömegben összezsúfolt

${ }^{4}$ Csáky Albin kultuszminiszternek a közoktatásról szóló az országgyúlés elé terjesztett 23. jelentése. 1894 . 86. o.). 
tanulók között igen gyakori volt a járványos megbetegedések száma. Másrészt, „[...] orvosok egész sora nyilatkozott egyre kritikusabb hangvételben a gyermekek túlzott iskolai igénybevételéről. Hangoztatták, hogy a rövidlátás mellett a fejfájás, az orrvérzés, az emésztési zavarok és az ún. "szükmellüség” - mind olyan betegség szimptómái, amelyeket az iskola okoz." (Pukánszky, 2001. 164-165. o.).

Érdemes áttekinteni azokat az írásokat és intézkedéseket, amelyek - mint látni fogjuk - egyre igényesebben és szakszerúbben fogalmazzák meg a jó iskolaépülettel szembeni elvárásaikat.

\section{KÖVETELMÉNYEK AZ ÉPÜLETEKKEL SZEMBEN A SZÁZADFORDULÓ KÖRÜLI ÉVTIZEDEKBEN}

Az iskolaépítészet és -felszerelés, valamint a tanszerellátás kérdéseivel is behatóan foglalkozó Gönczy Pál 1888-ban így fogalmazta meg a jó tanteremmel kapcsolatos igényeit: „A székek a gyermek korához mérve úgy legyenek szerkesztve, hogy azokra egymás háborgatása nélkül bejussanak, asztalaikon kényelmesen írhassanak. Fütése szellöztetö készülékkel legyen összekötve, az egy teremre 60 gyereknél többnek lenni ne legyen szabad, inkább ott, ahol egy tanitó 80 gyereket is kénytelen tanítani, a terem úgy legyen két részre osztva, hogy a tanító azt tetszése szerint nyithassa egybe, vagy különözhesse el egymástól. Legyen az iskolában a tanitónak lakása, s ha nem volna, köteleztessék az iskolát tartó község vagy felekezet a tanitónak ingyen lakás adására. $A z$ iskola udvara rendesen be legyen keritve, s kertté legyen alakítva, vagy legalább árnyas fákkal beültetve; az udvaron, vagy ha kivihetö az épület belsejében is testgyakorló helyiség legyen [...]

Az épület célszerü elrendezése, magassága, száraz volta, szellöztetése, a benne feltalálható kényelem, tisztaság, külső környékének csinossága, a gyermekeknek nemcsak egészségök épségben való fenntartására szolgál, hanem reájuk nevelöleg is nagy befolyást gyakorol." (Gönczy, 1888. 344-345. o.).

1890-ben Gerlóczy Zsigmond tette szisztematikus vizsgálat tárgyává Budapest iskolaépületeit, s tapasztalatait a főváros illetékeseihez is eljuttatta. Ez a vizsgálat számos negatívumot tárt fel, és bizonyosan hozzájárult, hogy 1892-ben „Emlékirat” készült az iskola-egészségügy, és ezzel szoros összefüggésben a jobb iskolaépületek érdekében. ${ }^{5}$

Az iskolaszékek közös javaslata szerint „,...népiskolák ne két-háromemeletes zárt épületekben, hanem legfeljebb egyemeletes pavilonszerüen elkülönitett szellős, egészséges helyen, amennyire lehet, decentralizálva helyeztessenek el, hogy az épületek jó fütö és szellözö rendszerrel látassanak el, hogy azokban a házilag elhanyagolt gyermekek testi nevelésére szolgáló iskolai mosdó- és fürdőhelyiség legyen, hogy az iskolaszolgák a rendszeres fertőtlenitésre begyakoroltassanak, és e célra külön helyiség rendeztessék be."

Ugyanebben az évben, 1892-ben Kolbenheyer Gyula - több nagy fővárosi iskola építője - elsősorban egészségügyi szempontból bírálta az iskolákat, illetve fogalmazta meg követelményeit. Véleménye szerint „,a szabályellenesen épített

\footnotetext{
${ }^{5}$ (Emlékirat az iskolai egészségügy érdekében. A fővárosi iskolaszékek közös értekezletének határozata. Budapest, 1892.)
} 
és berendezett iskolában elkorcsosul a gyermek zsenge testalkata, elsatnyul az ifjúnak még nem eléggé edzett egészsége. Az egészségtelen iskolákban szerzett gyógyithatatlan betegségek megmérgezik, s megröviditik az életét, vagy pedig már az iskolás évek alatt sírba döntik a tanulóifjúság jelentős százalékát." (Kolbenheyer, 1892. I. 16. o.). Két évvel később Kolbenheyer az Építő Ipar címú orgánumban többször is felemelte a szavát, és követelte az egészségügyi szempontok előtérbe helyezését (Kolbenheyer, 1894).

Írásaiban arra az álláspontra helyezkedett, hogy az iskolában el nem sajátított ismereteket lehet pótolni, de "a gyermeki szervezetben elöálló károk végzetesek lehetnek." (Kolbenheyer, 1894. 16.) Ha az iskolalátogatás kötelező - akkor adódik a morális felelősség, hogy a tanulókat ott egészségkárosodás ne érje -, mondja.

A célszerû és jó iskolával szemben alapkövetelményként a következőket sorolja fel:

- jó telek, egészséges föld,

- megfelelő csendes környék, elegendő hely az egyedülálló épülethez,

- a falazatok építóanyaga tégla legyen,

- a homlokzatok burkolata terrakotta legyen, a vakolás nem ajánlatos,

- a lépcsőt linóleummal kell borítani, hogy „incselkedés esetén ne legyen balesetveszély",

- a padló hézagmentes legyen, fából, vízálló anyaggal bekenve,

- a belső falakat faburkolattal vagy olajlábazattal kell védeni,

- az iskola előtt legyen előtér,

- a folyosók ne csak közlekedésre szolgáljanak, hanem adjanak módot kényelmes sétára, járkálásra is, ezért legyen világosak és fúthetőek,

- a ruhatár a folyosón legyen, vagy - angol mintára - a földszinti előcsarnokban,

- az ablakok mérete a terem alapterületének egyötöde-egynegyede legyen, s termenként négy-öt legyen beépítve (Kolbenheyer, 1894. 18. o.).

\section{III.1. A millenniumi iskolaépítési program}

A millenniumra készülve az 1890-es évek elején egy jelentősebb országos iskolaépítési program indult. 1896-ig - a tervezett ezerből - 400 új iskolát építettek meg Gönczy Pál fent vázolt elvei szerint. Sajnos, az új és korszerúbb iskolaépítési utasítás csak néhány évvel később, 1897-ben készült el, az Országos Közegészségügyi Tanács egyetértésével. (A terv csak részben valósult meg, és a négyszáz iskola építése is csak úgy teljesült, hogy új iskolának tekintették az egyházaktól átvett régi iskolákat is.)

Ennek értelmében minden iskolafenntartónak előzetesen be kellett mutatnia az új iskolaépület terveit a megyei közigazgatási bizottságnak. E szerv a tervdokumentációt a királyi tanfelügyelő, a megyei főorvos és az államépítészeti hivatal véleménye alapján hagyta jóvá. Ez az utasítás korszakos jelentőségú volt, mert előírta, hogy a tantermek 12 méter hosszúak, 6,3-6,5 méter szélesek, 3,8-4 méter magasak legyenek. Ablakokat csak az egyik hosszanti falon javasoltak. Az utasítás a falazatok építőanyagaként téglát ajánlott, de megengedte a terméskő, a vályog és a vert fal alkalmazását is. Jellemző, hogy az utasítás 
esztétikai szempontokat nem említett, ez csak később, 1907-ben merül fel, amikor a minisztérium azt javasolta, hogy az iskolaépületek tükrözzék a vidék építészeti sajátosságait, a tervezők alkalmazzanak a tájegységre jellemző népies motívumokat (Benisch, 1928. 112. o.).

Mivel az egyházi iskolákra ez az utasítás eleve nem vonatkozott, hatása jelentőségéhez mérten csekély volt. Jankovich vallás- és közoktatásügyi miniszter kötelezte ugyan az egyházakat korszerúbb iskolaépületek emelésére, de ennek fejében a rendelet minőségi engedményeket tett. A belmagasságot például már 2,4 métertől elfogadta.

1896-ban Fináczy Ernő A magyar középiskolák múltja és jelene címú írásában fogalmazta meg az ideális iskolaépülettel kapcsolatos igényeit. Tanulmányában ezt olvashatjuk: „[...] a Múzsák meg tudnak húzódni ideig-óráig kicsiny cellák szük falai között is, a müvelődés nemes kultúra, ha maradandó hatásra számít, méltó hajlék nélkül el nem lehet. Ott, ahol nemzedékek hosszú sorozata részesül az erkölcsi és szellemi képzés áldásaiban, a formák szépsége és szabályossága, a rend és tisztaság követelménye már magukban is nagy részét jelentik az igazi kultúrának." (Fináczy, 1896. 196. o.).

Két évvel később egy építész szaklap, az Építészeti Szemle szintén kettős, esztétikai-pedagógiai szempontból közelített az iskolaépítés problémaköréhez. „Az egész ország kulturális tendenciáinak példaképül szolgáló székesfóváros teljesen közönyös a pedagógia érdekeivel azonos esztétikai követelmények iránt. Iskoláink felépitésénél sem tágít szükkeblüségén, midőn azokat a hivatalos stílus szerint-akár a vízmedencéket vagy csatornákat - gyártatja." ${ }^{6}$ Kritikával illeti a Felső erdősor utca sarkán épült iskolát, amelynek hosszú tagolatlan homlokzata inkább gyárépületre hasonlít, mint iskolára.

A neves építész, Rerrich Béla ${ }^{7}$ véleménye szerint az iskolákat szándékosan tervezték rideg stílusban, mert törvény írja elő a kötelező látogatásukat. „Komor volt az és puritán, rideg és hangulattalan, nem is beszélve a modern hygiene fogalmai szerint való felsorolhatatlanul nagyszámú hiányról." (Rerrich, 1910. 13-14. o.). A századfordulót követő időszak egyik jelentős iskolája az 1904-ben átadott Istenhegyi úton épült intézet, melyet a szakemberek ,a legmodernebb kültelki” iskolának tekintettek. A kilenc tantermes iskola $2462 \mathrm{~m}^{2}$-es telekre épült. A beépített terület $868 \mathrm{~m}^{2}$ volt, ami rendkívül optimális, mindössze $35 \%$-os beépítettséget jelentett. A tantermeken kívül háromszobás igazgatói lakás és a gyakorlati foglalkozások céljára múhely is épült. A gondosan ápolt kertben üvegház, méhkaptárak, nyúlólak, galambdúcok kerültek elhelyezésre. Az iskola bútorzatát az iskolabútorok gyártásában országos hírnevet szerzett Feiwel Rudolf asztalosmester készítette. ${ }^{8}$ Az iskola történetét részletesen feldolgozva mutatja be Stolmár László a Budapesti Nevelő hasábjain. ${ }^{9}$

\footnotetext{
${ }^{6}$ Iskoláink építészete. In: Építészeti Szemle. 1898. II. 25-26.

7 Többek között a szegedi Dóm teret körülzáró épületegyüttes tervezője.

${ }^{8}$ Az istenhegyi úti iskola. Építö Ipar. 1904. 51.sz. 357.

9 Stolmár László (1975): Az istenhegyi (svábhegyi) iskola története. Budapesti Nevelő. 1975. 11. 1. sz. 88-89. o.
} 


\section{III.2. Higiéniai előírások ellenőrzése az iskolákban a századfordu- lót követően}

A fent említett esztétikai és pedagógiai szempontok mellett továbbra is az egészségügyi szempontok domináltak, amelyeket érthető módon a legkövetkezetesebben az iskolaorvosok képviseltek. A községi orvosok iskola-egészségügyben betöltött szerepét a VKM 1902. évi 44. 246. számú rendelete szabályozta. Az ebben foglaltak szerint a községi orvosoknak kéthavonta kellett ellenőrizniük az iskolában, hogy a padozat száraz-e? A szellőzés megfelelő-e? Van-e köpőcsésze? Az árnyékszékek tiszták-e? A ruhatár a folyosón került-e elhelyezésre? ${ }^{10}$

Az elő́rások betartása rendszertelen és sokszor ellenőrizhetetlen volt, pedig a miniszter arról is rendelkezett, hogy az új iskolaépületek terveit mindenkor tekintse meg az iskola orvosa is. A tanítók élet- és munkakörülményeit részletesen elemzi Baska Gabriella munkája (Baska, 2001. 74-75. o.).

\section{III.3. Mintaiskola építésének terve orvosok és egészségtanárok javaslatára}

A kormányzati rendelkezések mellett az Országos Közegészségügyi Egyesület iskolaorvosi és egészségtanári szakbizottsága 1905-ben javaslatot készített egy mintaiskola építésére.

Ez a mintaiskola nem valósult meg, de a tervek és javaslatok alapján megismerhetjük az iskolaorvosok követelményeit a korszerú iskolával szemben. Ebben a mintaiskolában nyolc tantermet terveztek, osztályonként 40 tanulóval. (!) Minden tanulóra $6 \mathrm{~m}^{2}$ alapterületet számítva. Ebből $2 \mathrm{~m}^{2}$ beépített területet, $3 \mathrm{~m}^{2}$ szabad udvarfelületet, $1 \mathrm{~m}^{2}$ szabad, de fedett játszóteret.

\section{III.3.1. Az épület és környezete}

A telek legyen távolabb a forgalmasabb fóútvonalaktól, a talaj és a környék levegője legyen tiszta. Ennek érdekében az iskolát olyan kisebb vagy mellékutcában kell elhelyezni, ahol pálinkafőzés nincsen és prostituáltak sem fordulnak elő.

A tanterem $10 \mathrm{~m}$, a hittanterem $7 \mathrm{~m}$, a rajzterem és a kézimunkaterem 12 $\mathrm{m}$, a tanácskozó terem $7 \mathrm{~m}$, a szertár $7 \mathrm{~m}$, az igazgatói iroda előszobája $3 \mathrm{~m}$, az igazgatói és az orvosi szoba $7 \mathrm{~m}$, az elkülönítő $3 \mathrm{~m}$ hosszúságú legyen. A múszaki leírás szerint minden osztálynak külön ruhatár kell, és két 10-10 m hosszú tanterem, napközi otthon céljára. A tornaterem a fóépülethez csatlakozóan épült, 10 × 20 m-es alapterülettel, hét méteres belmagassággal.

További követelményként jelentek meg az alábbi szempontok: Az alápincézett épület hosszfalas, oldalfolyosós legyen a megfelelő szellőztethetőség biztosítására, a tantermek bejárati ajtajánál küszöb ne legyen. A tantermek padozata beton aljzatra fektetett azbeszt padló, a tornateremé fúrészpor, homok és konyhasó keveréke. A falak 1,5 m magasságig mosható lábazati kialakítással készüljenek. A mennyezet mindig fehér legyen, az oldalfalak világos színúek

${ }^{10}$ Magyarországi rendeletek tára. Budapest, 1902. II. 1813-1814. 
mintázat nélkül. Az ablakok mennyezetig érjenek, és a keretek nélkül számított, tiszta üvegfelület területe a tanterem alapterületének egyötödénél kevesebb ne legyen.

Az iskolát légfútéssel fútsék, és az $18-20{ }^{\circ} \mathrm{C}$-t biztosítson. Az egyenletes fútést a tantermenként elhelyezett, a fútőnek automatikusan jelző hőméró segítse elő. Az iskolában indirekt fényt árasztó elektromos világítást javasoltak.

\section{III.3.2. A tanterem és berendezése}

Az épülő iskolák berendezésénél értelemszerúen a tantermek kívánták a legnagyobb figyelmet. Az iskolai padok kérdése ekkoriban már Magyarországon is évtizedek óta tanulmányok és viták tárgya volt. A külföldi tanulmányutak tapasztalatai alapján született meg az a döntés is, hogy néhány iskolában különböző külföldön használatos padrendszerekkel szereltek fel termeket, „hogy összehasonlításra tapasztalat álljon rendelkezésre."

A padok kiválasztásának főbb szempontjai a következők voltak: könnyû takaríthatóság, kis porfogó felület, szerkezetbeli egyszerúség. Ezek alapján a legmegfelelőbbnek az ún. küszöb nélküli padokat ${ }^{11}$ találták, amelyeknek akkortájt Németországban öt fajtája volt forgalomban, és mindegyik más-más gyártónak a szabadalma volt. Mégsem kellett importra gondolni, mert több elsőrangú hazai bútorgyár és ipartelep is berendezkedett a gyártásukra, úgy, hogy még az iskolaépítési akció okán jelentkező nagy padszükséglet fedezése sem ütközött nehézségbe.

Ezek a küszöb nélküli padok kétszemélyesek voltak, és az írófelület lapjának tanuló felőli éle és az ülődeszka első éle függőlegesen egy síkba esett. ${ }^{12}$ Készültek padok pozitív distanciával is, amelyek kényelmesebbek voltak, mert az írófelület síkja kissé felette volt az ülődeszka első élének. Valamint készültek padok negatív distanciával, ahol az írófelület kissé távolabb volt az ülődeszka élétől.

A korabeli véleményeket olvasva, az előbbiben ugyan kényelmesen, de kissé görbén ültek a tanulók, míg az utóbbiban ugyan egyenesen, de kényelmetlenül. Ezért a higiénikus és pedagógiai szempontokat figyelembe véve a nulladistanciás padok mellett döntöttek. Ezt követően kidolgozták iskolatípusonként a tanulók méreteit figyelembe véve a padszerkezetek különböző méreteit, különös tekintettel arra, hogy a háromféle iskolatípusban: elemi, polgári és felső kereskedelmi iskolákban, és azokon belül is osztályonként különböző méretú padokra volt szükség.

Összességében kilencféle padméretet állapítottak meg, amelyek közül a legkisebb az 1. sorszámú, az elemi első osztály 6-7 éves tanulóinak, míg a 9. sorszámú a 16-18 éves, vagyis a felső kereskedelmi harmadik osztályát látogató fiúk számára készült.

\footnotetext{
11 schwellenlose Bänke.

12 Ezt a változatot nevezték nulladistanciásnak. Bővebben lásd: Jáki László (1989): 55. o.
} 
1. táblázat. A padok jellemző méreteinek összefoglaló táblázata ${ }^{13}$

\begin{tabular}{l|l|l|l|l|l|l|l|l|l|l}
\hline Gyermekek életkora & $6-7$ & $7-8$ & $8-10$ & $9-11$ & $10-12$ & $11-13$ & $12-14$ & $13-16$ & $16-18$ \\
\hline A padok azonosító-száma & 1 & 2 & 3 & 4 & 5 & 6 & 7 & 8 & 9 \\
\hline Pad teljes magassága cm & 59 & 62 & 65 & 68 & 71 & 74 & 77 & 80 & 83 \\
\hline Ülés-magasság cm & 31 & 34 & 36 & 39 & 41 & 44 & 46 & 47 & 47 \\
\hline Távolság a belsó lap szélétól az ülésig cm & 24 & 24 & 25 & 25 & 26 & 26 & 27 & 29 & 32 \\
\hline Távolság háttámlától háttámláig cm & 64 & 64 & 64 & 66 & 69 & 69 & 69 & 71 & 71 \\
\hline A lap hajlása cm & 4 & 4 & 4 & 4 & 4 & 4 & 4 & 4 & 4 \\
\hline Az írólap szélessége cm & 35 & 35 & 35 & 38 & 38 & 38 & 38 & 39 & 39 \\
\hline Az ülés szélessége cm & 29 & 29 & 29 & 29 & 31 & 31 & 31 & 32 & 32 \\
\hline A lap és az ülés hossza cm & 110 & 110 & 110 & 110 & 115 & 115 & 120 & 120 & 120 \\
\hline Távolság lábközéptől lábközépig cm & 80 & 80 & 80 & 80 & 84 & 84 & 88 & 88 & 88 \\
\hline
\end{tabular}

Egy tanterembe két, vagy háromféle méretû pad került. Elhelyezésük kétféle módon történhetett. Vagy a legelső sorokba állították a legkisebb, és a leghátsó sorokba a legnagyobb padokat, vagy oszloponként helyezték el a különböző méretú padokat, például úgy, hogy az ablakokhoz legközelebb eső padsor a legkisebb, a középső valamivel nagyobb, az ajtó melletti padsor pedig a legnagyobb padokból került ki. A soronkénti padnövekedésnél a következő beosztást alkalmazták:

Az elemi iskola első osztályának tantermeiben az első padsorok - az összes padok fele - 1. azonosítószámú, a középső padsorok - az összes padok egynegyede - 2. azonosítószámú, és a hátsó padsorok - az összes padok egynegyede - 3. azonosítószámú volt.

Az elemi iskola felsőbb: második, harmadik, negyedik, ötödik és hatodik osztályánál a 2., 3., 4., 5., 6., azonosítószámú padokkal a tanterem berendezése az első osztályéhoz hasonlóan történt.

A polgári iskolákban az első osztály legkisebb padja az 5. azonosítószámú, a második osztályé a 6., a harmadik osztályé a 7. és a negyedik osztályé a 8. azonosítószámú padokból került berendezésre.

Az oszloponkénti padelrendezésnél egy-egy oszlopba csupa egyforma méretú padot helyeztek el, úgy, hogy például az első osztályba az 1. azonosítószámú pad két oszlopba, a 2. azonosítószámú pedig a harmadik oszlopba került, és így tovább a többi osztályokban, szükség szerint két- vagy háromméretú paddal, illetve padoszloppal berendezve.

\section{III.3.3. A tantermek további bútorzata}

A tantermek második legfontosabb berendezési tárgyai a táblák voltak. Ezért minden teremben felszerelésre került a nagyméretú fekete színú falitábla, egymás mögött két-három külön mozgatható és lehúzható vagy lapozható táblalappal, továbbá a katedra, dobogóra helyezett tanári asztallal, és a tanteremszekrény.

\footnotetext{
13 Szombatfalvy György. (1913, szerk.): A magyar népoktatás hiányai. In: Magyar Népoktatás. VKM. 54.
} 
A szekrény általában kétszárnyú ajtóval felszerelve, egyik oldalán a tanulók, a másik oldalon a tanító iskolaszerei számára kialakítva. Az egyszerú deszkára csavarozott ruhafogasok a folyosón kerültek elhelyezésre. Néhány iskolában kísérleti jelleggel acélrácsos ruhatári szekrényeket is beépítettek a folyosón kialakított falfülkékbe (Erdei, 1991. 81. o.). A ruhatárban minden tanulónak biztosítani kell egy fiókot törülközőjének és poharának elhelyezésére (Bexheft, 1905.).

A fentiekben részletesen ismertetett mintaiskola tervdokumentációját szemlélve egyrészt jól megragadhatók a dolgozat bevezető fejezetében - Foucault szemlélete alapján - megfogalmazott modernizációval együtt járó fegyelmező folyamatokra törekvő szándékok, másrészt az egyén - jelen esetben a tanulóvá váló gyermek - feletti állami társadalmi kontrollra törekvés. Az egyre differenciáltabbá váló intézményrendszer - jelen esetben a már mindenki számára kötelezővé tett elemi iskola -, válik az ellenőrzés és fegyelmezés napi gyakoriságú színterévé.

A Fodor József és munkatársai által megfogalmazott és egyre erőteljesebben szorgalmazott korszerú higiéniai elvek gyakorlati megvalósulását bizonyítja, hogy azok nemcsak 1905-ben, hanem több vonatkozásban máig korszerúnek számítanak, és mint látni fogjuk, a későbbi - részletesebb - követelmények sem tudták lényegesen meghaladni azokat (Szabó, 1906. 249-253. o.).

Egy évvel később egy iskolaorvos, könyvében azzal érvelve igyekezett nyomatékot adni követeléseinek, hogy „,az elemi iskola a kultúrának ama járma, melyen keresztül kell menni az egész nemzetnek. Ezért az iskola-egészségügyi követelmények megtartása az épitkezések során alapvetően fontos." (Domitrovich, 1906). Ügyében szövetségeseket keresve a szerző az építészekhez fordult. Egyáltalán nem véletlen, hogy az iskolaorvos írását először az Építő Ipar címú folyóirat közölte. ${ }^{14}$

1912-ben ugyanez az orgánum foglalkozott falusi iskolák építésével, megfogalmazva az azokkal szemben támasztott követelményeket is. A tanulmány szerzője, Rerrich Béla építész fontos feltételként említette, hogy az iskola tervezésénél vegyék figyelembe annak környezetét. Rerrich épületeit egy korabeli országos napilap úgy kommentálta, hogy: „[... ] ezek az iskolák valóban kedves, meleg fészkei a falusi apróságoknak." (Idézi: Jáki, 1989. 17. o.).

\section{IV. ÖsszegzÉs}

Áttekintettük a századforduló iskola-egészségügyének hazai fejlődését, melynek nyomán megvalósultak a kor pedagógiai szakemberei, iskolaorvosai és építészei által áhított higiénikus iskolai terek. A gyermek mint tanuló egészségének felértékelődése és fókuszba kerülése egybecsengett a XX. század elején kibontakozó reformpedagógia irányzatok gyermekközpontú szemléletével is.

Amint azt Németh András is hangsúlyozta: „[... ] a modernizációs folyamatok eredményeként a XIX. század második felében az európai iskolaügy fejlödésének egy új

${ }^{14}$ Domitrovich idézett munkája először a folyóiratban jelent meg. Épitő Ipar. 1906. II. 11. 
szakasza vette kezdetét. ... A század végére Európa-szerte létrejöttek a nyilvános, kötelező, új szakmai szinten kialakított, és általános szinten megfogalmazott feladatokat ellátó, állami jóváhagyások és elvárások szerint müködő nemzeti közoktatási rendszerek, amelyek a század végére a kontinens legtöbb országában magukba fogadták a gyermeknépesség nagy részét. A népoktatás állami jóváhagyása, támogatása, finanszírozása - amely a XX. századra a nemzetállami fejlödés világszerte intézményesülő közmüvelődési modelljének egyik fontos elemévé válik majd - először Közép-Európában jött létre." (Németh, 2012. 49. о.).

A mottóként választott - Gönczy Pál által 1888-ban megfogalmazott - felismeréssel teljesen egyetértve állíthatjuk, hogy e tág értelemben vett higiéniai elvárások a Bárczy-féle iskolaépítési akció során - 1909 és 1911 között - megvalósult 36 budapesti iskolapalotában és a Rerrich Béla tervezte falusi iskolákban már kétség nélkül teljesültek.

E korszak budapesti iskolaépületeit a szerző - máig kiadatlan - disszertációjában ${ }^{15}$ már részletesen elemezte. Az ott feltárt összefüggések; a korszerú pedagógiai környezetnek egyrészt az oktató-nevelő munkára, másrészt a gyermek testi-lelki egészségre gyakorolt pozitív hatásának elemző bemutatása azonban már egy újabb tanulmány témája lesz.

\section{IRODALMAK}

\section{Önálló Könyvek}

Canguilhem, M. (2004): A normális és kóros. Gondolat Kiadó, Budapest.

[Sine nomine] (1892): Emlékirat az iskolai egészségügy érdekében. A fővárosi iskolaszékek közös értekezletének határozata. Budapest.

Fináczy Ernő (1896): A magyar középiskolák múltja és jelene. Budapest.

Foucault, M. (1990): Felügyelet és büntetés. A börtön története. Gondolat Kiadó, Budapest.

Illyefalvi Lajos (1925): A közoktatásügy Budapesten a világháborút megelőző években, Budapest.

Jáki László (1989): Korszerüsítési törekvések a századforduló iskolaépitésében. OPKM, Budapest.

Kunfi Zsigmond (1913): Népoktatásunk bünei. Budapest.

Németh András (2012): Magyar pedagógusképzés és pedagógus szakmai tudásformák I. 1775-1945. ELTE Eötvös Kiadó, Budapest.

Pukánszky Béla (2001): A gyermekkor története. Múszaki Könyvkiadó, Budapest.

\section{Szerkesztett könyvek}

Baska Gabriella (2001): Fények és árnyak. In: Baska Gabriella, Nagy Mária és Szabolcs Éva (szerk.): Magyar tanító, 1901. Iskolakultúra, Pécs. 59-83.

Kéri Katalin (1995): A katolikus elemi iskolák állapota Baranyában. In: Baranya - Történelmi Közlemények 1994/95. VII-VIII. évf., 197-221.) Letöltés: https: //kerikatalin.files.wordpress.com/2015/01/katelisk.pdf 2017. 02. 04.

${ }^{15}$ www.ppk.elte.hu/file/sanda_istvan_daniel_dissz.pdf 
Mikonya György (2015): Mozaikok Eötvös József pedagógiai munkásságából. In: Donáth Péter (Szerk.): Filozófia - múvelődés - történet, 2015. Trezor Kiadó, Budapest. 135-153. (Az ELTE Tanító- és Óvóképző Karának Tudományos Közleményei, XXXVI.)

Mikonya György (2015): Gyertyánffy István a tanitóképzés megújításáért. In: Donáth Péter (szerk.): Filozófia - múvelődés - történet 2015. Trezor Kiadó, Budapest. 153-169. (Az ELTE Tanító- és Óvóképző Karnak Tudományos Közleményei, XXXVI.)

Pogány Frigyes (1928): A magyar népoktatás története. In: Szombatfalvy György (szerk.): A magyar népoktatás. A M. Kir. Vallás- és Közoktatásügyi Minisztérium, Budapest. 148-181.

\section{Könyvfejezetek}

Benisch Arthur (1928): Az iskolaépítési akció. In: Szombatfalvy György (szerk.): A magyar népoktatás. M. Kir. Vallás- és Közoktatásügyi Minisztérium, Budapest.

Bexheft Ármin (1905): A gyermekmüvészeti kiállítással kapcsolatban tervezett mintaiskola épitésének és berendezésének szem elött tartandó egészségtani alapelvek. Az Országos Közegészségügyi Egyesület iskolaorvosi és egészségtan tanári szakbizottságának javaslata alapján. Budapest.

Erdei Gyöngyi (1991): Fejezetek a Bárczy-korszak történetéből. Fővárosi Szabó Ervin Könyvtár kiadása, Budapest.

Gönczy Pál (1888): A népoktatás Magyarországon. In: Gönczy Pál (1888): Tanulmányok. Budapest.

Nóbik Attila (2015): Professzionalizáció és iskolai tér Az elemi Népoktatás Enciklopédiájában. In: Baska Gabriella és Hegedûs Judit (szerk.): Égi iskolák, földi múhelyek. Tanulmányok a 65 éves Németh András tiszteletére. ELTE PPK, Budapest. 91-107.

Szombatfalvy György. (1913, szerk.): A magyar népoktatás hiányai. In: Magyar Népoktatás. VKM Kiadása.

Folyóiratban megjelent cikkek

Antall József - Kapronczay Károly (1975): Fodor József és az iskolaegészségügy. Magyar Pedagógia. 51. 2. (191-200.)

Aujenszky Aladár (1905): Fodor József emlékezete. in: Nemzeti Nőnevelés. 29.

[Sine nomine] (1907): A modern iskolaépítés. Népmüvelés. 2. 4. 333-337.

[Sine nomine] (1907): A tanszemélyzet közremúködése a fertőző és a ragályos betegségek elleni küzdelemben. Népmüvelés. 2. 4. 244-250.

Bély Mihály (1906): A test gyakorlása. Népmüvelés 1. 3. 94-95.

Dékány Mihály (1903): Néhány adat egy gráci iskola berendezéséről. Magyar Tanitóképző XVIII. évf. 2. 234-238.

Domitrovich Ármin (1906): Az iskolaszoba egészségügyi igényei. Budapest. Különlenyomat. (Első megjelenése: Építő Ipar. 1906. 02.11.)

Fodor József (1885): Középiskolai hygienetanárok és iskolaorvosok. Orvosi Hetilap. 1885.

Fodor József (1887): Iskolaorvosok és egészségtanárok a középiskolában. Egészség. 1887. 
Fodor József (1890): A kisdedóvásról szóló törvényjavaslat. Orvosi hetilap. 1890.

[Sine nomine] (1898): Iskoláink építészete. Építészeti Szemle. VII. 2. 22-30.

[Sine nomine] (1907): Iskolaszobák világítása. Népmüvelés. 2. 385386.

Kabdebó Gyula (1906): Mintaszerú iskolaépület. Népmüvelés 1. 8083.

[Sine nomine] (1904): Az istenhegyi úti iskola. Épitó Ipar. 2851.sz.

Katona Ibolya (1963): Orvosok harca a századfordulón a középiskolások szellemi túlterhelés ellen. Medicina 1963. 27. (135-139.)

Kolbenheyer Gyula (1892): A budapesti mintagimnázium épülete. Épitési Szemle,. I. 16.

Kolbenheyer Gyula (1894): Az iskolák építése és berendezése. Épitő Ipar. 18., 19., 20., 22., 23., 28. szám.

Mikonya György (2002): Két Herbart-tanítvány: K. V. Stoy és W. Rein az iskolapedagógia megújításáért. Iskolakultúra, 12. 5. sz. 27-38.

Németh András (2008): A néptanítói tudás konstrukciója Az elemi népoktatás enciklopédiájában (1911-1915). Iskolakultúra, 18.. 5-6. sz. 86-103.

Rerrich Béla (1910): Múvészet a népiskolában. Építő Ipar. 34.1910. 2. sz. 1314.

Stolmár László (1975): Az istenhegyi (svábhegyi) iskola története. Budapesti Nevelo".

Szabó Sándor (1906): Mintaszerú iskolaépület. Népmüvelés. 1. 249-253.

Tigyiné Pusztafalvi Henriette (2013): Az egészségnevelés intézményesülésének története. Educatio. 2013/2. 224-234.

Tóth Kálmán (1906): Gyermekeink védelme. Népmüvelés 1. 139-140.

Jelentések

Csáky Albin (1894): A VKM. miniszternek a közoktatásról szóló az országgyúlés elé terjesztett 23. jelentése. Magyarországi rendeletek tára. Budapest, 1902. II. 1813-1814.

Kézirat, kiadatlan szakdolgozat, disszertáció

Sanda István Dániel (2009): A pedagógiai terek vizsgálata - Különös tekintettel a XX. századi magyar iskolára. PhD értekezés. Kézirat. ELTE Neveléstudományi Doktori Iskola, Budapest. Letöltés: http://ppk.elte.hu/2009/images/stor ies/_UPLOAD/DOKUMENTUMOK/Nevelestudomany_Phd/sanda_diszertacio.pdf 2017. 02.04 . 